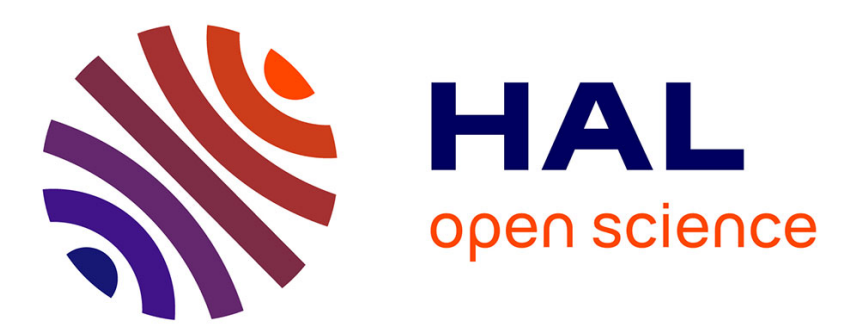

\title{
Tusans (tusheng) and the Changing Chinese Community in Peru
}

Isabelle Lausent-Herrera

\section{To cite this version:}

Isabelle Lausent-Herrera. Tusans (tusheng) and the Changing Chinese Community in Peru. Journal of Chinese Overseas, 2009, 7 (1), pp.115-152. 10.1163/179325409X434522 . halshs-00598152

\section{HAL Id: halshs-00598152 \\ https://shs.hal.science/halshs-00598152}

Submitted on 4 Jun 2011

HAL is a multi-disciplinary open access archive for the deposit and dissemination of scientific research documents, whether they are published or not. The documents may come from teaching and research institutions in France or abroad, or from public or private research centers.
L'archive ouverte pluridisciplinaire HAL, est destinée au dépôt et à la diffusion de documents scientifiques de niveau recherche, publiés ou non, émanant des établissements d'enseignement et de recherche français ou étrangers, des laboratoires publics ou privés. 


\title{
Tusans (tusheng) and the Changing Chinese Community in Peru
}

\author{
Isabelle Lausent-Herrera*
}

\begin{abstract}
Since their arrival in Peru 160 years ago, the Chinese have struggled to form a community. Faced with hard living conditions, scattered in haciendas, deprived of Chinese women and suffering from racism, mistreatment and restrictive immigration laws, the task of keeping alive seemed insurmountable. Paradoxically, the emergence and consolidation of the Chinese community came about through mestizaje and conversion to Catholicism. This mestizaje allowed them to rebuild the Chinese family structure, though an internal hierarchy appeared depending on the degree of mestizaje. The Catholic Church also played a role as artisan of Chinese identity by helping at the very beginning with the organization of associations and by strengthening the sense of belonging and recognition of the Tusans (tusheng in Mandarin) or "local born" as part of the Chinese community. However, the new immigrants from China, arriving since the 1980s, have contested the legitimacy of the Tusans and posed new challenges to the local Chinese community. How and to what extent has this new Chinese immigration changed the community life and reinforced/weakened the Tusan identity? This article describes the historical development of the old Chinese community and analyzes the interaction between the Tusans and the recently arrived Chinese.
\end{abstract}

\section{The Beginnings}

Plagued by political instability and the prospect of freeing the African slaves, the reconstruction of Peru after independence had been slow. It was only in 1846 that the opening of the guano and the increase of sugar exports to Europe brought in the necessary capital for modernization of the infrastructure of the young Republic. This new-found income also allowed the state in 1854 to free the slaves by compensating their owners. In order that production would not be adversely affected, Domingo Elias, hacendado, eminent liberal and progressive politician, had a law passed in 1848 to encourage immigration. This

* Isabelle Lausent-Herrera is a researcher at the Latin American Research and Documentation Center (CREDAL) of the National Scientific Research Center of Finance (CNRS). Her email address is lausent.herrera@gmail.com. 
law, called Ley china, allowed the introduction of an indentured work force from China thanks to an extremely lucrative commercial enterprise which replaced the slave trade.

More than 100,000 coolies $^{1}$ were thus brought to Peru between 1849 and 1874. This large group of immigrants was characterized by its masculinity, the almost total absence of women. ${ }^{2}$ During their contract, which ran from four to eight years, often longer depending on the goodwill of the hacendados, the men had almost no contact with the local women, particularly African women. ${ }^{3}$ But in the cities, and especially in Lima, ${ }^{4}$ where they were employed as domestic servants and artisans and where they enjoyed greater liberty, there was the formation of Sino-Peruvian households - as evidenced by the first mixed-raced births listed in the parish records - from the beginning of the 1850 s. According to this source, the majority of the women companions, lifetime or temporary, were not originally from Lima but the coastal and Andean provinces. Rarely servants, these women often ran small shops and it can be said that they contributed, by helping out and sharing their experience, to the establishment of the first small businesses of the free Chinese. ${ }^{5}$

In the rural milieu, it was more difficult to form union with women, even for Chinese liberated from their contracts. According to the traveler, Ernest Middendorf, they at times had recourse to Chinese matchmakers who carried out collective ceremonies during which young serranas or indigenas were married to them (Middendorf 1993: 262-63; Lausent-Herrera 2006: 294). ${ }^{6}$ Apart from this form of union, other households were formed depending on the wanderings of the Chinese; some were in flight, some were refugees, and some

1 The 1876 census registered 49,956 Chinese - a figure slightly underestimated - out of a total population of 2,699,160 inhabitants. Between 1849 and 1876 nearly half of the Chinese brought into Peru (aged from 9 to 40, rarely older) died from exhaustion, suicide or ill treatment.

2 Women made up less than $1 \%$ of the Chinese recorded. In 1851, José Sevilla, importer of Chinese, presented to the Chamber of Senators a report on the problems posed by this imbalance and recommended, in vain, the bringing in of families and Chinese women (BNP, Miscelánea Zegarra.XZ.V.58: p.37). Some women were nevertheless brought in from 1860 when commerce with China increased and the first Chinese merchants from California settled in. Traces of them can be found particularly in the cemeteries - open to converted Chinese from 1870. See Lausent-Herrera (1992 and 2006).

${ }^{3}$ On this theme, see Cuche (1976).

${ }^{4}$ In 1876 nearly 12,000 Chinese were living in the capital; they represented $10 \%$ of the urban population at that time.

5 The national archives show that numerous Chinese living with Peruvians worked in the same shops, particularly butcher stores (AGN,T647,1891), (AGN, T906,1888).

${ }^{6}$ In the 1880s young women from the Andean communities of the central Andes began to come to work seasonally in the coastal haciendas. The Chinese preferred the indigenas acclimatized to the coast to African women. 
households were established in the Andean communities on the Amazonian borders of the Andes or in the Amazon region. ${ }^{7}$

\section{The injertos: A New Asiatic Caste in the Republican Universe of Peru}

As part of Peruvian society, the Chinese were not inconspicuous and their appearance, as well as the fact that they had wives and children, disturbed and offended the Peruvian observers and intellectuals many of whom were brought up on racial prejudices inherited from the Colony and nourished by the works of Spencer, Le Bon and the hygienists who condemned the crossbreeding resulting from the union between Chinese and Peruvians, which in their view could lead to the degeneracy of Peruvian society. Clemente Palma (1897: 36) described in offensive terms the sight of this new miscegenation in Peruvian society:

Although this race crossbreeds with difficulty and the fruit of this crossbreeding has little chance to live, it is dangerous because of the vices it teaches our people and the maladies it leaves in them, which, even if the women are not fertile, finally remain in their blood, thinning it, weakening them and giving disastrous results (Palma 1897). ${ }^{8}$

This perception of crossbreeding as a stain and a degeneration characteristic of the Colonial period was still held by the elite during the Republican period. Clemente Palma's ideas would be taken up again to the end of the 1930s, a time when anti-Chinese racism was spread not only through pamphlets and manifested in violence but also enforced by law.

What is interesting here is that no authors who castigated the fruit of such unions, no priests, no missionaries and no municipal agents, were able to fit the group into their traditional classification. ${ }^{9}$ The arrival of the first Chinese coolies made necessary the inclusion of a new racial component into Peruvian

7 On these themes, see Lausent (1983), Lausent-Herrera (1996 and 1998).

8 Clemente Palma's assertions against crossbreeding were taken up again 20 years later in the same terms and with the same conviction by Sixto Santisteban: "We are not among those who believe that a privilege of the races exists; however, it cannot be denied that our race is debased by contact with the Asiatic race and that crossbreeding of the American and the yellow degenerates and weakens it." Santisteban (1905: 8) (translation from Spanish).

9 The complexity is even greater since there already were in Lima, before the introduction of the coolies, the Chinos de Manila who arrived in the 17th century and the mixed blood "yndia con mulato" called chinos or chinas which could lead to confusion with the use of chino or china (see the classification made under the Viceroy de Montesclaros, "Padrón de los Indios de la Provincia de Lima en 1613” (Lima, UNMSM, 1968). See also Cook, 1985. 
society, that is, the raza amarilla o china represented by the chinos de la Gran China, chinos del imperio celeste, and Celestes or Nación asiática as the most respectful terms; los amarillos or Macacos were the popular, deprecating adjectives also used in the newspapers. On the other hand, the generation of the first half-Chinese which became visible from 1870 was not called by any name.

Like Edmond Cotteau (1886), Marcel Monnier (1890: 111), another French traveler, was speechless when he tried to describe the new "mixture": "the type coming from the relations of the Chinese coolie and the woman of the indian or black race has not yet received a special denomination," the term mestizo being reserved in most cases for children born of Indian or Spanish fathers or mothers. Such hesitation, such classifications, revealing of the state of mind of the time, were due mainly to the fact that, as has already been noted, the Republic had not accepted the Chinese half-breeds, the fruit of "racial degeneracy." They had not "officially" been given a name, and therefore a place. The written form of the term injerto or transplant appeared only at the beginning of the 20th century.

It is impossible to know exactly when the term injerto appeared and when it was applied to Chinese-Peruvian half-bloods. The term brings to mind the world of agriculture, and no doubt originated in the rural classes in contact with the Chinese working in the haciendas. In addition, it seems to refer to only the mixed race children of Chinese and native women viz. indigenas, indias, cholas et natives, and not the Afro-Peruvians. Used for a long time in the domain of popular speech with no pejorative connotations, it was taken up in the press and in official papers only at the beginning of the 20th century, and thereafter became offensive.

Deprived of Chinese wives, ${ }^{10}$ these injertos or half-bloods made up the first group of a local-born Chinese community in Peru. The very young girls or injertas were particularly desired in marriage, either to mixed race Chinese or Chinese freed from their contracts, especially from $1870 \mathrm{on}$. As such, from the second generation the household thus created approached that of the Chinese model. ${ }^{11}$ This return to the model of Chinese kinship after passing through the obligatory stage of a mixed-blood generation reflects the desire of the first Chinese to regain their identity ${ }^{12}$ and to become organized as a community. In 1868 the first native place associations (buiguans), viz. the Ku y Kong

${ }^{10}$ On this theme, see Lausent-Herrera (2006).

${ }^{11}$ Concerning the strategies used to reconstitute the Chinese families and conserve a minimum of traditions, see Lausent (1983: 70-121).

12 One notes also at the same time a great number of Chinese who renounced the Spanish names they had adopted on their arrival and took up again their Chinese names. 
(Guangzhou), the Hakka association Tungshing (Tongsheng) and that of Canton (the future Punyui or Panyu society) petitioned, in the name of the Chinese ill-treated in the haciendas, for protection from the Emperor of China. Between 1881 and 1895, a group of Chinese, encouraged by the Catholic Church, sought to create an association capable of protecting all of them. The arrival of Zheng Zaoru, the imperial emissary, put an end to this initiative, however. Zheng ordered the creation in 1886 of the Sociedad de Beneficencia China, the Tonghuy Chongkoc ${ }^{13}$ and La Beneficencia, to be led by representatives of the great Chinese commercial enterprises, themselves directors of the huiguans. These men would henceforth defer to the ambassador of China posted to Washington; they were also the only community representatives recognized by the Peruvian authorities. Influenced by the climate of reform then prevailing in China, they were enterprising and far more educated than the first group of Chinese. Being responsible for maintaining the social order, they established an elitist hierarchy based upon social and economic success thus relegating the first Chinese immigrants to the ranks of ordinary members. A large part of the half-bloods originating from the first generation - those preceding the installation of this new order within the community - would be absorbed over time into the Peruvian population, though not without difficulty. ${ }^{14}$ Another group, offspring of a succession of intermarriages, would remain within the community, acquiring little by little certain economic and social success, and take up traditional practices again such as returning to China for a Chinese bride and sending the children there to study. ${ }^{15}$

In the new community hierarchy we thus find at the top the merchants and owners of the big enterprises, the local directors of the huiguans, themselves merchants, the commercial managers, and sons or relatives of the directors who were educated in China and brought over by their parents. Below them were the children born in Peru of Chinese fathers and mothers, the famous

13 On the origin of the formation of the Chinese community, see Lausent-Herrera $(1997,2000)$.

${ }^{14}$ Between 1887 and 1895, the Peruvian army conscripted the mixed blood Chinese-Peruvians. Manuel Lazure, a Chinese, protested to the Legation, saying that his son "is subject to His Majesty the Emperor of China and that he had been enrolled by force." This example illustrates, among other things, the difficulty of both the first Chinese fathers and the first half-bloods to situate themselves in a society which did not welcome them.

15 From the beginning of the century the father sent his daughters and sons to China, sometimes accompanied by their Peruvian mother. The children, taken in either by the first wife or the paternal grandmother's family, received a Chinese education which served them when they returned, either in helping the daughter to get married to a Chinese established in Peru, or the son to find work in the large commercial establishments such as Wing On Chong or the Pow Lung. These practices, customary in Lima, were also observed in large provincial cities as far away as Amazonia. See Lausent-Herrera (2006). 
Tusans or native-born; but their standing in the community would depend on their knowledge of the Chinese language as well as the level of their economic success. After them came the children born of a Chinese father and a halfblood mother. Last in the order were the children born of a Chinese father and a Peruvian mother (Lausent-Herrera (1997: 134-40).

Thus despite the internal political dissentions, there was the consolidation of a Chinese community with fewer and fewer mixed blood members. As the new migrants continued to be predominantly male, the alliance with halfChinese women or native born Tusan women did not cease. Owing to the absence of reliable national censuses between 1876 and 1940 it is not possible to establish the size of the incoming migrants. ${ }^{16}$ But there is little doubt that it was big enough to bring about a rich community of artisans, small businessmen and employees. Because of the scarcity of female immigrants, the expansion of the community depended upon the voyages to China for matrimonial purposes. Very often, the Chinese who had settled in Peru looked for the young half-blood girls and Tusans born in Peru and who were sent to study in China (mainly Macao) or to stay with their Chinese family. This situation led to unrest in 1909 when there were popular uprisings calling for, among other things, a halt to Chinese immigration. The signing in the same year of the Protocole Porras-Wu Tingfang obliged China to control and restrain the immigration of its subjects to Peru. Owing to the prevalence of corruption in both countries, immigration did not slow down despite the increasingly drastic restrictions in Peru. According to A. McKeown (2001: 147), from 1910 to 1930 , during the protective regime of President A .B. Leguía, the entry of 12,263 Chinese was recorded. The overthrow of A .B. Leguía by Commander L. M. Sanchez Cerro not only drastically reduced Chinese immigration ${ }^{17}$ (to a quota of $20 \mathrm{a}$ month), but also marked the beginning of the anti-Asiatic laws lasting until World War II. According to one national census in 1940, there were only 10,915 Chinese residents in Peru. ${ }^{18}$ However, for the period from the beginning of the 20th century to World War II, the community progressed, ${ }^{19}$ developed, became integrated and modernized. Also during these

${ }^{16}$ For an assessment of different sources quantifying Chinese immigration, see McKeown (1996). However, it is difficult to estimate with precision the importance of Chinese immigration due to illegal entries at the Chilean and Ecuadorian borders and via the Peruvian Amazon River (Manaos-Iquitos route).

${ }^{17}$ A substitute clandestine immigration was set up via Ecuador; numerous young women promised in marriage to the Peruvian Chinese took this route. The network via Guayaquil was also set up after the establishment of the Communist regime.

18 Ministerio de Hacienda y Comercio, Dirección Nacional de Estadística. 1940. "Censo Nacional de Población y Ocupación de 1940. Lima.

19 This period has been studied by Lausent-Herrera (1997) and McKeown (2000: 138-77). 
years the half-bloods and the Tusans (children born in Peru of both Chinese parents) won, little by little, their own space and the recognition of the chinos legitimos.

In 1909, the Chinese empire was on its last leg; many progressive Chinese overseas were active in the anti-Qing movement especially through the press. In Lima a young Tusan, Juan Iglesias (Chan Kaichu, 1878-?), who had perfect command of both Chinese and Spanish, was working as translator for the Chinese Legation. ${ }^{20} \mathrm{He}$ was assigned to assist Minister Wu Tingfang (Chinese Ambassador to the United States) who had come to Peru to sign the PorrasWu Tingfang Protocol in relation to the limitation of Chinese immigration. The same year also saw the publication of the review, El Internacional, with the encouragement of Wu and the local support of Juan Iglesias. The review, which appeared only a few times, supported the reformist ideas of Li Hongzhang. Two years later the Chinese in Peru, divided politically but not to the point of being torn by fratricidal conflicts as in Cuba, produced two new newspapers, La Voz de la Colonia (Kum Yen Po/Kongyan Bao) ${ }^{21}$ in 1910 which defended the position of the Chee Kung Tong (Zhigontang), and the Man Shing Po (Minxingbao ${ }^{22}$ which supported the new Republic of Sun Yat-sen. The case of the native-born Juan Iglesias is exceptional, for at this time the universe of the chinos natos ${ }^{23}$ or huaqiao was especially restricted. Despite the modernity of their political ideas and commercial practices, the only way for them to preserve their culture and their identity was, for those who were married, to send the women and children to China or, for those as yet unmarried, to bring in wives from China. Such arrangements could only be made by an elite group able to use bribe or pay the expenses of such an enterprise, particularly at the time when the Wu Tingfang Protocole was in force. Even if they could speak Cantonese or were fortunate enough to be sent to China, the Tusans were in their large majority - cut off from institutional or political activities. As for the half-bloods, they were definitively excluded. Hence, for this reason, and sharing the socialist ideas of their fathers, they were drawn to the movements of students, intellectuals and workers mobilized in Peru to put an end to the conservatism of the oligarchic creole society.

\footnotetext{
${ }^{20}$ He had previously worked as departmental head in a large commercial company, Hop On Chong, in Lima.

${ }^{21}$ Inaugurated on March 2, 1910.

22 Inaugurated on March 10, 1911, twice a week, then daily in 1917.

${ }^{23}$ Chinos natos (those born in China) is a popular, non pejorative term employed in Peru to designate the first generation of Chinese immigrants.
} 


\section{Dissonant Voice of the First Injerto}

Pedro Zulen Aymar (1889-1925) ${ }^{24}$ was one such half-blood who chose to devote his political thinking to the improvement of the lives of the Indians, the most oppressed group in Peru society. Son of a modest Chinese merchant and a Peruvian, Pedro Zulen studied in a Peruvian secondary school - exceptional at that time - before entering San Marcos University. He divided his life between his academic career (in philosophy and logic) and his engagement in the Indian cause. In 1909, he co-founded the Asociación Pro-Indígena to which the great intellectuals ${ }^{25}$ of the generation of the 1920s belonged. In 1912 and then from 1920 to 1922 he studied at Harvard University. He became a candidate in the regional elections of Jauja in the Central Andes in 1909 which made him the very first politician of Chinese origin in Peru. However, he was arrested and imprisoned just before the election on charges of being a Bolshevik and was disqualified from participating in the election to be deputy. In retrospect, 1909 and 1919 were two significant years in the short life of Pedro Zulen. In 1909 he united within his association the Peruvian intellectuals in promoting the cause of the Indigenas, at the time when antiChinese riots by the working classes broke out in Lima. The riots were so violent, murderous and devastating for the Chinese that Ambassador Wu Tingfang came to Peru to defend the interests of his countrymen. ${ }^{26}$ Ten years later, in January 1919, other equally violent and murderous riots took place against the Chinese led by the workers of the Federación Obrera Regional Peruana, ${ }^{27}$ who fought for the right to an eight-hour working day. The riots led to the destruction of shops in the Chinese quarter and violence against the Chinese and the Japanese. Among the instigators and leaders of this movement was another Chinese half-blood, Adalberto Fonken, a textile worker from Vitarte and an anarcho-syndicalist.

${ }^{24}$ His name is sometimes spelled: Sulem Aymar.

25 Those belonging to the Association included Alfredo Gonzales Prada, writer and first propagandist of "Anarchism in Peru," Alberto Ulloa, José de la Riva Agüero, Victor Andrés Belaunde and the journalist, Dora Mayer. For a better understanding of the thinking of Pedro Zulen, his intellectual work and his influence on Peruvian treatment of the Indian population, see Leibner (1997).

${ }^{26}$ May 10, 1909, rioting workers led by F. Caceres, candidate for the office of deputy, destroyed the Chinese quarter, shouting "death to the Chinese!" The next day the mayor of Lima ordered the destruction of a block of houses where hundreds of Chinese lived.

${ }^{27}$ In 1917 among the members of the guild of bakery workers - in direct competition with the Chinese - were the founders of the Liga Antiasiatica. 
On these two occasions Pedro Zulen said nothing. Other intellectuals of the time such as Mariategui also kept their silence. ${ }^{28}$ At no time did Zulen denounce or criticize the racist demonstrations targeting the Chinese and their descendants. Did he feel so different from the Chinese, being a mixed blood, or was this a deliberate political stance that he had chosen? Leibner (1997; note 19) thinks that Pedro Zulen had "renounced his otherness": even if it was a political choice, it was difficult to believe that he was able to remain unmoved by what was happening in the streets.

Could it be that as half-blood intellectuals and unionists, Pedro Zulen and Adalberto Fonken were totally cut off from the Chinese community? In the case of Fonken, this is possible, although at this time several of those who were sons of Chinese ${ }^{29}$ like him were members of the APRA (Alianza Popular Revolucionaria Americana, 1924) whose founder Haya de la Torre claimed all the while that the alliance was inspired by the Kuomintang and the Revolution of 1911.

In the case of Pedro Zulen, the links between the Chinese community and this educated and scholarly half-blood were not severed, contrary to what Leibner believes. In 1913 the Asociación de los Commerciantes Chinos en el Perú offered him the position of honorary secretary, a position he refused saying that he was preoccupied with other duties and could not serve to the best of his abilities (Boletin Bibliográfico de la Biblioteca San Marcos, $\mathrm{n}^{\circ} 1$ October 1923, p. 2). Even if this platonic relationship was very embarrassing for him, Pedro Zulen was very close to the journalist, Dora Mayer, director of the

${ }^{28}$ It is interesting to note that Pedro Zulen's stand - which came as a shock because his father was Chinese - was also that of the majority of the intellectuals surrounding him who, like him, were Pro-Indigenistas. Only racist attitudes toward the Indians was considered condemnable while the attitude of members of the working class who saw the Chinese as foreigners who "eat the bread of the people," was not worth combating. In 1908 the feminist journalist, Maria Jésus Alvarado (close to Pedro Zulen's circle) who defended in her writings the anarchosyndicalist thesis distributed among the working class, was one of those who began to use publicly the term injerto in all its pejorative sense (Lausent-Herrera 2006: 298, note 31). This view was also shared by the oligarchy. For example, the Peruvian Consul at Hong Kong, B. Seoane, wrote the next year: "in Peru the Chinese compete with the working class and impoverish them, leaving behind them the detestable heritage of the injertos, who have received from their fathers only their vices and none of their virtues, this to the clear detriment of our native race." (Archives of the Ministry of Foreign Relations, 8.23A: Peruvian Consulate in Hong Kong, May 22, 1909). It thus seems clear that for Pedro Zulen, even if he was in contact with the "Chinese world" and no doubt admired by a part of the elite among the Chinese merchants, there was only one clear choice. If one caste should be defended in Peru, it was the Indians, the legitimate inhabitants of the country and not the new immigrants and their descendants who had no place and of whom no legitimacy was recognized.

${ }_{29}$ Notably V. Polay-Risco, cofounder with V. Haya de la Torre of the newspaper La Tribuna and the political party $A P R A$. 
review, El Deber Pro-Indigena, and great defender of Chinese immigrants to Peru. Finally, in 1923, when Pow Sanchia (Xie Baoshang, 1860-1939), president of the Chinese community ${ }^{30}$ and the most powerful and respected person among his countrymen, offered a gift of 200 Peruvian pounds to the University of San Marcos which was presented to Pedro Zulen who had just been nominated director of the University library and entrusted with the responsibility of cataloguing the library holdings (Boletin Bibliográfico de la Biblioteca San Marcos, ${ }^{\circ} 1$ October 1923). ${ }^{31}$

Therefore there existed a relationship, based on recognition or ideological affiliation between some Chinese half-bloods and the Chinese community. In 1925, at the death of Pedro Zulen, Enrique Bustamente wrote in an article in Variedades titled "Pedro S. Zulen, Una pérdida Nacional" (Variedades, ${ }^{\circ} 883$, $3161,1925)$ in which he implied that, for Zulen, a half-blood, the road to recognition by the intellectuals was a belated and difficult one.

\section{The Modern Nationalist Voice of the Tusans or the Longing for Recognition}

Between the establishment in 1899 of la República Aristocrática and the end of the regime of A .B. Leguía in 1930 the Chinese community fortified itself. In fact, the new Chinese who arrived at this time replaced the former coolies and their leaders who organized affairs in the native-place associations; these newcomers had the capital and shared with the members of the local oligarchy and important foreign entrepreneurs established in Peru the same vision of future investments in major projects relating to agricultural exports, mining development, manufacturing, international commerce and the colonization of new territories. Despite the political instability which accompanied the country's transformation, the rising demands of the budding working class and above all the increasingly virulent anti-Asiatic racism, ${ }^{32}$ the leaders of the Chinese community prospered and behaved like members of the bourgeoisie.

\footnotetext{
${ }^{30}$ Aurelio Powsan Chia no doubt intervened through his legation to defend his countrymen but publicly he remained discreet and diplomatic.

${ }_{31}$ Boletín Bibliográfico de la Biblioteca San Marcos, $\mathrm{n}^{\circ} 1$ October 1923. See also San Marcos' Library official web page http://sisbib.unmsm.edu.pe/exposiciones/pzulen/Vida/vida1.htm "Pedro Zulen, San Marcos y su tiempo.”

32 At the beginning the population rejected the Chinese. When the new rule admitting Japanese immigrants was introduced into Peru thanks to A .B. Leguia, twice president of the Republic, the demonstrations and pamphlets targeted the latter as well. The Japanese, although rejected by the population, were protected during the 11 years (1919-1930) of Leguia's second term. While the Chinese were denied entry, the Japanese obtained a great number of authorizations. See Lausent-Herrera (1991).
} 
Their thriving joint stock companies boasting of different Cantonese investors from Hong Kong, California and, to a lesser extent, China, were flourishing in Peru. The principal ones were Pow Lung (1896), Pow On (1897) and Wing On Chong (1872) which were directly linked to the Ton Huy Chong Koc. The stockholders held diversified investments through buying and managing the negociaciones agricolas, haciendas of sugar, cotton and even animal husbandry; they set up La Union, an insurance company, the Chumwha Navigation Company Ltd, a navigation company, and a Chamber of Commerce. Besides the large commercial companies, the Chinese and Tusans, at times in conjunction with the half-bloods, developed small local industries especially in the provinces which made them the agents of modernity.

The growth in the number of migrants despite the policy of immigration control was sizable, ${ }^{33}$ as reflected in the increase of all forms of associations, particularly the brotherhood associations and fraternal-political associations, with the engagement of important members of the community during these years. In 1920 there were 30 associations - not counting the huiguans founded in the different regions of Peru, and numerous guilds (doctors, shoemakers-repairers, butchers etc.) besides those on the list produced by the Beneficencia China (Bilu Zhonghua Tonghui Zongju yu Bilu Huaren, 1986: $217)^{34}$ in 1886.

In 1924, a publication appeared with the title, "The Chinese Community of Peru. Its institutions and outstanding members. Its beneficial contribution to national life." ${ }^{35}$ Edited by the Benefícencia China, it is testimony to the eminent positions held by members of the elite of the Chinese community we are not speaking here of the immigrants or of the descendants of coolies who had succeeded economically and contributed to the prosperity of the country. It was also to show that the community had produced remarkable men, some educated internationally, who shared qualities of excellence with the nascent Peruvian high bourgeoisie. ${ }^{36}$ Some rare references were made to

33 There were no censuses in Peru between 1940 and 1961, however there was evidence corroborating this increase: opening of commerce, multiplication of associations, registry of marriages, etc.

34 In 1920 the political engagement of members of the community was shown by a great number of brotherhood and fraternal-political associations.

35 "La Colonia China en el Perú. Instituciones y hombres representativos. Su actuación benéfica en la vida nacional."

${ }^{36}$ It is in this spirit that in 1917 the Chinese bought a piece of land in order to set up their own tennis club in the seaside resort of Miraflores which was becoming urbanized. The club was opened in December 1917. The Peruvian review, Variedades, saluted this event in an article entitled "el deporte del tennis en la colonia." The comments were subtly sarcastic and racist, alluding to the fact that "in its upward march, the Chinese Colony does not miss an occasion to copy 
their Tusan collaborators or to those among them who formed a family in this country ("formaron su hogar en este pais") without saying if they had taken in Peru a wife of Chinese or Peruvian origin.

\section{Oriental: Birth of the Tusan Community}

Into this idealized world as portrayed in various community journals, a new Peruvian Chinese culture was born: modern in tone, ideas and form. Its voice was the journal Oriental (Dongfang yuebaol Tonfu Yipo). Its founders, Alfredo Chang Cuan (Chang Hongweng, 1911-1992) and his cousin, Gabriel y Leonor Acat Cuan, launched themselves into the venture in 1931. Alfredo Chang was born in Trujillo, cradle of the APRA, of a Chinese father married to a mixed-blood Chinese woman. At his mother's death about 1922 he went with his father to China where he was left in the care of his father's family. When he returned to Peru and settled in Lima, he was 19, and very distressed by the political crisis which divided China and its vulnerability in face of the Japanese. Together with his cousin, Gabriel, and initially with another cousin, Leonor, and then with his future wife, Guillermina Ruíz Chong, also a Tusan, Alfredo Chang mobilized his future sponsors, the big Chinese and Peruvian wholesalers, in financing the production in April 1931 of the first issue of a publication where he exhibited a strong Chinese nationalism. He explored in Spanish - with a ten-page insert in Chinese - the most diverse themes affecting Peruvian society such as the world situation, cinema, the position of women etc. This journal also had as its aim to report on all social events concerning the Chinese half-bloods (the injertos), and the Tusans residing in Lima and in the province. Thanks to this monthly publication the Tusan spirit was uplifted, and the Tusan community was presented as an economic, social and even political entity vis-à-vis the group representing the "legitimate" Chinese (those born in China) who controlled the fortunes and direction of the regional associations, the native-place associations and above all the representatives of the Kuomintang in Peru.

With the Japanese invasion of Manchuria, the content of the editorials was radicalized and became very nationalistic. As in Chinese overseas communities everywhere, the publication sought to foster Chinese nationalism in all its forms. Thus, Alfredo Chang, very touched by the situation in Guangdong when he left China, decided upon returning to Peru to pass himself off as a "legitimate" Chinese so as to be able to integrate into the Kuomintang, to

white civilisation by taking what, among other things, is best in it, that is the practice of sports, such as tennis, an elegant sport reserved for the elite." 
climb the rungs of community power and above all to enlarge the influence of his journal. The political engagement of the journal contrasted with the lightweight, worldly or feminine articles designed to appeal to the Tusans and mixed-blood public who did not read Chinese and knew very little of their fathers' history.

In 1931 the Chinese in Peru found themselves in a difficult situation not only because the country was suffering from the economic effects of the Great Depression beginning in 1929 but also because a dictatorship had come to power which would last until World War II. Successive governments passed laws not only prohibiting immigration but also restricting the freedom of the Asians and their descendants who were born in Peru but who were also registered with their respective legations (such as laws nos. 7505 and 7705 on foreign quotas authorized to do business, Oriental $n^{\circ} 36$, January 1935). During the Japanese invasion of Manchuria and the great famine that struck the Guangdong region, Oriental criticized ${ }^{37}$ the directors of Benefícencia China for their lack of initiative and community work, their narrowness of spirit, and their discriminatory measures against the Chinese and the Tusans.

One of the important victories scored by Oriental was in calling upon the first-generation (China-born) Chinese to give more respect and consideration to the injertos and the Tusans. In its editorial of November 1934, Oriental urged the Chinese ambassador to "give back their dignity to the descendants, born of Chinese parents in Peru, and to try to become closer to them." Oriental stressed:

This idea should be welcomed with pleasure because it benefits our collectivity. For it is true that those who are called "injerto" have not in the past been considered by our compatriots as well as they should have been... It is a fact that they didn't obtain the social recognition to which socially they have a right.

The Chinese ambassador responded by persuading the Chinese to take advantage of law 7505 to hire Chinese-blood Peruvians. ${ }^{38} \mathrm{He}$ added:

[T]he "injerto" carries his race reflected in his physical traits. He cannot deny his paternity. He is made to work with his own people and he is in the privileged

${ }^{37}$ See for instance the appeal launched by Javier Loo Kung to "his dear compatriots and their sons," to boycott the Japanese products sold in Peru: Oriental, n 12, May 1932.

38 This law particularly forbade Asian (Chinese and Japanese) merchants to have more than $20 \%$ of foreigners among their personnel and to employ a member of the family. What Oriental meant was that by employing an injerto, a half-blood to whom he was not related and who would be Peruvian by birth (jus soli), the Chinese businessman would have the advantage of having in his business a faithful employee with Chinese features, authorized by law. 
position of mastering two languages and making himself understood perfectly by the Peruvians as well as by the Chinese.

The hour has come for the sons of Asians to feel they are true Chinese and the Chinese to feel "injertos" ... Our paisanos [compatriots] ${ }^{39}$ should understand that the isolation of one or the other branch is unfavourable to the interests of the colony and that this behaviour will keep them from progressing.

Written in an outmoded style and vocabulary, the reasoning of Oriental may appear ambiguous, for it did assert first that the injertos were completely Chinese and at the same time also Peruvians. Now that the Chinese needed them to support the war effort, they argued that the Tusans and injertos should be given more consideration. This was based on the reasoning that the Tusans and injertos, both in need of recognition in a country where anti-Asian racism was more and more oppressive, would respond to such mobilization for the defence of an invaded China. In so doing they would prove their attachment to and affiliation with China.

Following this editorial and encouraged by the ambassador, the Manshing Po and La Voz de la Colonia carried out a campaign to bring together the Chinese born in China and the Tusans and injertos. To be accepted and appreciated by the Chinese born in China, they had to show a veritable and sincere patriotism for China.

A second journal, New Chung Wa, founded in October $1934,{ }^{40}$ followed Oriental in the latter's crusade both to rehabilitate the Tusans and half-bloods not by integrating them into Peruvian society — as no doubt they considered themselves already part of it — but by making them return to their roots. The debate raised by Oriental on the theme of the injertos and their rehabilitation was taken up by a reader of New Chung Wa, Luis T. Lu Carliche, who was in favor of collaboration. Lu Carliche defined himself as an injerto, a technical term which signifies "el cruce de dos razas definidas" ("the breeding of two well defined races") but also an integral part of the Chinese community because of his engagements with it and his mixed blood of which he was proud. What he

\footnotetext{
39 Although the ambassador was speaking strictly about the Chinese born in China, the term paisano refers to both a compatriot born in China and the Chinese born in Peru (Tusans) and by extension a half-blood Chinese.

${ }^{40}$ This journal paid attention to the education of youth, the problems of society such as health and the position of women. The tone was pacifist despite supporting China and one senses the influence of the Catholic Church upon its authors. Since the foundation of the college, the Jesuits had the right to give courses in religion to the young pupils. After that the youth would be organized in Catholic associations, no doubt also to counter the appearance of the YMCA. From 1961 on the Chinese curacy of Peru was entrusted to the Franciscans.
} 
desired was a strong union between the two generations (New Chung Wa, $\mathrm{n}^{\circ} 15$, January 1936, p.14).

Thus by 1939, the Chinese community, which the generations who arrived in 1890-1929 had built on the model of economic success, discreet patriotism and non-interference in Peruvian political life, had fallen apart and disappeared, at the same time that its most eminent representative, Powsan Chia, passed away. The ideas and initiatives launched by Oriental and then The New Chung Wa had modified the structure of the Chinese-Peruvian community as well as the perception that the descendants of the Chinese had of themselves. This initiative accorded with the new policy of the Overseas Chinese Affairs Commission (1932) which decided to send to the overseas communities professors ${ }^{41}$ and scholarly material, and to support local initiatives aiming to forge a strong Chinese identity in uniting the Chinese and their descendants.

At the end of World War II and after the establishment of the People's Republic of China, the community was shaken and a number of families were broken up. Up until 1937 the Chinese of Peru were still sending their women - among whom Peruvians and their children — to China to receive a Chinese education, because the secondary schools in Lima could not offer the perfect education they wanted. ${ }^{42}$ For many years, children and parents were separated and communications were cut off. It was through the Taiwanese and Hong Kong networks that arrangements were made for the clandestine return of not only those who had stayed on in China - as Peru had barred them from returning for fear of Communist infiltration - but also for the entry of relatives who had never been to Peru but who wanted to flee from China. Many among the Hakkas from Zhongshan County, particularly Chiqi, had already a part of their family sent to Macao and Hong Kong since the 1920s, a period when the sending of the Sino-Peruvian children ${ }^{43}$ (girls and

${ }^{41}$ Peru benefited from this program particularly by being sent a specialist in the editing of journals in Chinese and professors. See The New Chung Wa, 1935, n 12, pp. 23-27.

42 The existing schools were the secondary school Chungwha created in 1924 and the San Min (Three Principles of Sun Yat-sen: Nationalism, Democracy, Social Welfare) founded in 1925. In 1934 the director was Gabriel Acat, co-director of Oriental.

${ }^{43}$ It is interesting, in this respect, to see that contrary to what A. McKeown claims (2001:47), the religious networks between Peru and China not only existed but also served to help young girls of mixed blood (from Catholic secondary schools in Macao) and Tusans to be married to Chinese residing in Peru or wanting to immigrate to Peru. A document of the Ministry of Foreign Relations MRE (6-11) of June 28, 1938 thus authorized the entry of a young Chinese girl with a certificate of engagement to marriage delivered by the Catholic Mission of Chiqi (Chockai). Between 1949 and 1961 the link between the church in China and that of Peru was loosened although some Jesuit missionary work on the spot continued, especially through the young Catholic associations, both to keep them in the Catholic religion and to save their Chinese identity by favoring marriages between Tusans and half-bloods and accepting religious 
boys) to Catholic and Protestant secondary schools rapidly increased. The clandestine road passing through Guayaquil which had been used during the preceding regimes saw a redoubling of its activity.

In Peru, the aggression against the Chinese community, widespread during the military dictatorships of L. M. Sanchez Cerro (1930-1933) and O. Benavides (1933-1939), came to a halt. However, the post-war governments, civilian and military, were no more clement toward the Chinese community insofar as they did not authorize, with exceptions, the return of those who had been retained in China. It is impossible to know the number of Chinese who were able to enter Peru during the years $1949-1965 .{ }^{44}$ It is reasonable to assume that there were many, for it is still common to find among those between 60 and 80 years old who, entering by Ecuador or Panama, have acquired a new identity on their arrival in Peru. The huiguans, previously active agents of exchange with the mother country, particularly in helping with the settlement, not always legal, of new arrivals and in the sending to China money for the families, were destabilized. They had now to find other means of maintaining their networks in China and bringing in new migrants. The great houses of commerce which had been active in Guangdong and Hong Kong were also affected by the closing of China. From then on, the community turned to Taiwan.

\section{Disillusions}

In Peru the Chinese realized that returning to the mother country had become impossible. The reconciliation between the generations so much desired by the Tusans before the war had come naturally but before long the internecine quarrels over the future of Communist China began. In this respect, the journal Oriental which had put all its energy into defending the values of the

marriages with clandestine Chinese newly arrived and not baptized (parish marriage records, San Pedro Church, Lima).

${ }^{44}$ From 1950 to 1955 the frontier was completely closed to the Chinese who were barred from entering as well as leaving. In April 1955, Ambassador Chu Shushi obtained for the Chinese of Peru the right to travel. This permission was above all given to the Chinese wishing to go to Taiwan for political reasons. A request was later made on the basis of an authorization of return and entry for the Chinese who had been retained in the People's Republic or who had a relative in Peru and wished to leave China. In reality the new Immigration Law of February 3, 1958 (intended for the Chinese and Japanese) allowed the entry of only 150 people a year. The conditions required for entry were so restrictive and the possibility of getting out of China was practically zero such that other ways — illegal — were used to resolve difficult family situations. In 1965 only 33 Chinese were legally authorized to enter Peru. See Ho Mingchung 1967: 11. 
Kuomintang found itself rather disoriented editorially after the war. In 1953, when the country fell under the dictatorship of General M. Odria (19481956), the journal was pessimistic: "China no ha logrado la paz" (China has not won the peace). How could it be that the coalition of the democracies was not able to re-establish peace? What would the Cold War entail and what would be Taiwan's future? ${ }^{45}$

There was a sense of withdrawal on the part of the eldest from the institutions of which they felt they were the guardians, while the young generations looked to their future in Peru. The term injerto disappeared; little by little the term Tusans was recognized and began not only to reunite the descendants of Chinese parents but also to include certain half-bloods in their associations. In the provinces, more than in Lima, the recognition of and praises for the Tusans, due above all to their strong mobilization during the war, enabled the communities to survive. This young generation, between 18 to 30 years old, still desired to gather together in the political, religious and social organizations; however, pragmatically, they realized that their future was in Peru. ${ }^{46}$ Their future depended now on the role which the Tusans could play in Peruvian society. The traditional commerce, battered by the economic crisis and the scarcity of supplies in Asia, was abandoned for the liberal professions like engineering, medicine and law. After the depression of 1953 the Chinese and the Tusans began to invest in all sectors of the economy: industry, agriculture, fisheries; they continued to stay away from the mining sector which was traditionally controlled by the oligarchy and its foreign associates. Under the dictatorship of General Odria (1948-1956) who clamped down on social unrest for a while, and also under President M. Prado Ugarteche, the Chinese and Tusans of Peru profited from the encouragement given to private enterprise by establishing start-ups. The great commercial enterprises such as Pow Long and Pow On were confined to the Chinese quarter and no longer played the same role in the community; their time of splendor was over.

\section{New Hopes for the Peruvian Tusans}

The 1960s was an interesting time in Peru-Taiwan relations. While the frontiers were slow to open for the Chinese, Peruvian politicians were not hostile

\footnotetext{
45 Oriental, December $1953, \mathrm{n}^{\circ} 259$. Note that the Chinese advertisers, very numerous before the War, had almost disappeared.

46 There were of course parents who insisted, out of hope, nationalism and political conviction, on sending one or several of their children to Taiwan or Hong Kong and even to Communist China, but they were few.
} 
to the nationalist government of Taiwan. In 1961, after paying an invited visit to Taiwan, President Prado congratulated himself on discovering a democratic China on its way to modernity. ${ }^{47}$ In 1963 and 1964 other political personalities were invited, all of whom stressing the desire for social progress displayed by Taiwan - a theme taken up by both the Peruvian Left and Right. In 1966, Victor Haya de la Torre, founder of APRA, was invited to give conferences, and was extremely well received in Taiwan. For his part, Haya de la Torre praised the success of the agrarian reform and the industrialization of his host country.

The interaction of commercial and industrial interests among the Chinese, Tusans and Peruvians was immense, as shown clearly in the monthly Diario Commercial China and the newspaper of the Chinese merchants in Peru, Huashang ribao. This was an indication of not only the total integration of the majority of the Chinese and their descendants into Peruvian society but also, for a great number of them, the radicalization to the right and political conservatism. Nostalgic for the military regime of Odria, the writers for the publications were ferociously anticommunist and denounced with equal vehemence the strikes and demonstrations of the Peruvian students as well as the Great Leap Forward, in support of the APRA and the Peruvian government. Whether in the pages of Oriental, Huashang ribao, or a little later on in those of La Voz de Oriente ${ }^{48}$ (Dongfang zhiyin), one notes in the media the active participation of numerous Tusans in public life.

\section{The Church's Role: Artisan and Guardian of the Tusan Identity}

From 1870, the integration of the Chinese and their children was marked by religious conversion. It seems that the Hakkas, already quite numerous at that time, were the ones who converted earliest. Between 1882 and 1885, they were, with the support of the Peruvian church and Monsignor Giovanni T. Raimondi, Cardinal of Hong Kong, who were the principal backers behind the formation of a great Chinese charitable organization, federating all other associations already in existence. ${ }^{49}$ On his arrival in Peru at the end of 1884,

47 From 1960 on, the Huashang ribao, Diario Commercial Chino, May, n 1526, PeruvianChinese monthly, hailed the enthusiastic return from Taiwan of a parliamentary commission which recommended after this visit that Peru persevere in its struggle against Communism and in its belief in God!.

48 Illustrated magazine of 1968.

49 Archivo Arzobispal de Lima, "Carta de Comunicaciones, 7 de noviembre 1883; Carta de Kuh Tacqui (alias Manuel Benavides), Presidente de la Beneficencia China al Ilustrísimo y 
Ambassador Zheng Zaoru took over from the Church and the government the control of the Chinese community and handed it over (so that it would prosper) to the successful Chinese merchants who would later become the directors of the huiguans. With that the relations then existing between the Church and the community leaders was broken. The evangelization of the Chinese was thus carried out discretely from then on, even as relations between the clergy in China and the community continued. In Lima the evangelization of the poorer Chinese was in large part the work of the beatified Dominga Gazcón. ${ }^{50}$

It was through the access to education that the Church would recapture a part of its control over the community, at least over the Tusans and their parents. First, with the help of the Peruvian wife of the president of the community, Pow Sanchia, the Peruvian wives of the Chinese or half-bloods created in 1898 the first association of "damas católicas de la comunidad china" (Catholic Ladies of the Chinese Community). This was based on the reasoning that the organization of women was the first step to improving education which in turn was essential for integration. The first Tusans, supported by the Tong Huy Chong Kock, established a secondary school, Chung Wha, in 1924 which was followed by the San Min. Influenced by the progressive ideas spread by the nationalism of Sun Yat-sen, the Tusans were open to new educational experiences and agreed to have a Jesuit chaplain put in charge of religious education for those who wanted it. In 1934 it was the Spanish Jesuit, Jacinto García, who took charge of the educational development of the young children until they became adults. The associations of young Catholic Tusan men and women also brought together numerous young people leading to marriage, thus bringing about certain stability in the Tusan community. Often the isolation, lack of support, and incomprehension felt by the Tusans were compensated by the sense of belonging and recognition brought to them by the religious figures they encountered, particularly the Jesuits of the San Pedro Church. Two important stages can be noted: the first, after World War II and the arrival of Communism in China, and the second, after 1972 and the departure of the Taiwanese Ambassador, followed by the takeover by the Communist diplomats of all the Chinese institutions in Peru. It was at these two moments that the Franciscans, followed by the Jesuits, took control of the education of the younger generations of Tusans and brought them into the Church, supposedly without making them lose their identity.

Reverendísimo Señor Arzobispo del Perú; Carta del 22 septembre 1883 de Kuh Tacqui a nombre de la Sociedad Asiática de Beneficencia al Señor Provisor y Gobernador Eclesiástico."

${ }^{50}$ For further developments on this point, see Lausent-Herrera (2008). 
After 1949, there were persecuted priests who succeeded in leaving China after several years of imprisonment and turned to the overseas Chinese communities. Monsignor Te Shien-Kao, Franciscan and Bishop of Guangzhou, came to Lima in 1950. Before him, Monsignor Yu-Ping had brought catechism in Chinese and in English to the Chinese of the San Pedro Church. Father Francisco Keng from an old Catholic family in Hebei who had fled China in 1953 also came to Peru to visit the Chinese secondary schools. But the person who definitively left his mark on the Chinese community was Monsignor Orazio Ferrucio (1911-1990), Bishop of Kichow. Having been expelled from China in 1952, he was made responsible for the Chinese clergy of Peru from 1955 by Pope John XXIII when the project of a large secondary school was then underway. Monsignor Ferrucio arrived at a difficult time for the Chinese community whose members saw in this religious figure who spoke Chinese, kept in contact with China and who had suffered in the Communist jail, a sort of guardian of the Chinese identity of the Tusans. The journal Oriental also played a part in playing up this reassuring and charitable image of the Catholic Church. In 1960, Francisco Leon used the journal to appeal to the Tusans to form an association which would work with Monsignor Ferrucio and help him build a secondary school. ${ }^{51}$ The Tusan Club was thus founded in 1961 with the collaboration of the Franciscans led by Juan Wu. This led to the establishment in 1962 of the secondary school Juan XXIII (John XXIII), which became the seat of the clergy consecrated to the Chinese in Peru and their families. In return, the two secondary schools, Chung Wha and San Min, where nationalist values were inculcated in the students, and where the teachers were often Protestant, merged the same year into one school, the Diez de Octubre.

The post-war Tusan Club was very different from that created by Oriental in 1931 which was above all nationalist. Another generation of Tusans was now asserting itself. In 1964 everything had changed and so had the Tusan youth. In opening the school to the descendants of the Chinese and in welcoming the several generations of half-bloods, the Church in a certain way had made the condition of the Tusans normal. From then on the Tusans and the Peruvian Church would be linked, for there is no better way of social integration other than through church attendance. This closeness with the Tusan youth allowed the Church - which took charge of education and culture in Chinese - to maintain good relations with the Sociedad de

${ }^{51}$ In asking the members of the Tusan association to collaborate in the creation of a school and to send their children there, he entered into competition with the secondary school Diez de Octubre. 
Benefícencia Central China although this group was more favorable to the Diez de Octubre school.

During the 1960s, certain Tusans began to involve themselves in matters outside the economic and became engaged in Peruvian political life, as Pedro Zulen had done before them, but in isolation. Intellectuals such as the philosopher Victor Li-Carrillo (1929-1998) and Emilio Choy Ma (1915-1976) chose to enter politics by studying. A self-taught Tusan, the latter came out with an innovative Marxist reinterpretation of the history and anthropology of Peru. In politics, the leftist movement was making headway in Peru and reaching the middle classes and the students. For the Chinese community traumatized by the advent of the People's Republic of China, the sure values remained anticommunism, Taiwan and the Church. For this reason the community was perturbed in 1964 by the decision made by France, one of the world powers, to recognize the People's Republic, to the detriment of Taiwan. Would the democratic powers let down the Chinese Nationalists once again? (Oriental, 1964, n 385.)

\section{To Stay or To Leave?}

In 1968 General J. Velasco's coup d'état put an end to the neoliberal policies. The agrarian reform which Belaunde had not been able to carry out was thus vigorously pursued. Expropriations and the confiscation of agricultural properties and industrial enterprises touched a number of Chinese and Tusans of the older generation. It is not known how many families of Chinese origin chose then to leave Peru. Following the example, still vivid in memory, of the Chinese of Cuba who chose exile in 1959 after Fidel Castro took power and left for the United States, an unknown but large number of Peruvian Chinese chose to leave for the West Coast of the United States and Canada. The coup de grâce was given by the Velasco government in 1971 when it recognized the People's Republic of China, thus accelerating the departure of the Chinese from the country.

In the same year Oriental made a new appeal. "What is happening with the Tusan youth?" asked Jorge Lam. Even if the Chinese institutions were paralyzed, even if the community was completely divided by political events, the Tusans should not desert it. Juan Wu, who had founded the Tusan Club in 1961, launched the same appeal: "Get to work, young people in the Tusan association!" Aware of the fact that a "vital cycle" was coming to an end, Lam and $\mathrm{Wu}$ appealed to them not to give up, but to take up the relay, so that the gap would not widen between the members of the older generation who strove 
on strict morality and the young who no longer believed in the conservative institutions of the community. In its November 1971 editorial, Oriental made a poignant appeal (Oriental, 1971, $\mathrm{n}^{\circ} 470, \mathrm{p} .22$ and $\mathrm{n}^{\circ} 473$ ) to the readers to address the concerns of the young Tusans who were looking toward the People's Republic. That would not prevent Oriental, a free journal, from dispensing information on Communist China and claiming to be the only link between the Peruvian Chinese community and the government of Chiang Kai-shek.

This was a time when the Chinese community, as much as the entire population of Peru, was presented with a trial. Because of the restrictions on imports, Wing On Chong (dating from 1872), the last symbol of success of Chinese commerce in Peru, disappeared, and the directors of the associations faithful to Taiwan had to leave, taking their archives with them and leaving the premises to those who sympathized with and supported Communist China among whom were the post-1949 migrants and the Tusans who had gone to study either in Hong Kong or in the People's Republic. The changes in Peru, which came about between 1971 and the return to democracy in 1980, are very well observed and recounted in the novels of Siu Kamwen, a young Chinese who arrived with his parents in Peru in 1960. One can read in "El tramo final" how individualism took the place of community spirit, how the population of mixed races spread and with that came the end of traditions including respect for the parents. The young looked toward Canada while the old closed their shops and remembered their arrival in Peru 60 years earlier.

Despite the construction of a beautiful gateway at the entrance to the Chinese quarter by the government of Taiwan in 1971 (just before Peru chose to recognize the People's Republic of China), the inhabitants of the Chinese quarter were dwindling; many were leaving for the more comfortable parts of the city, particularly San Borja. The modern and more spacious Chinese restaurants also moved out to other more bourgeois neighborhoods, offering thanks to the arrival of new Chinese cooks - new dishes while conserving those of the creole Chinese cuisine special to Peru. But Chinese migrants continued, in much smaller numbers than before certainly, to enter Peru illegally. Changing their identity on arrival with the help of the huiguans, they integrated with few problems, the population of Lima having got used for decades to living side by side with Chinese who spoke Spanish badly and worked in the restaurants.

\section{The New Soul of the Tusans: A Generation of Shorn Hopes}

The decade of the 1980s saw a total change in the life of the Chinese in Peru and the Tusan youth. Deprived of the freedom of speech during the years of 
the military dictatorship, the return of democracy allowed the Tusans to enter, now officially, the political life of Peru. In 1978 Rubén Chang Gamarra of the Partido Popular Cristiano (PPC), a Tusan, was persuaded to be a member of the future Constituent Assembly which was charged with holding future elections. In 1980, several members of the Chinese community were elected: Eugenio Chang Cruz and Ruben Chang Gamarra for APRA, and Ernesto Lao Rojas for the party in power, Acción Popular. Ernesto Lao Rojas who had lived in the Amazon region, represented Loreto, in support of Belaunde's ambition of opening up the eastern provinces of Ucayali and Loreto. Dr. Juan Wong Espinoza also supported Action Popular so as to increase social security; his cousin, Enrique Wong-Pujada would be elected deputy of Callao in 1985. Victor Polay Risco ${ }^{52}$ (1904-1994), son of a coolie, represented the APRA of which he was one of the founders. He was a member of the parliament's education commission, having promoted the improvement of literacy skills among the working class and the upgrading of professional training. But the longawaited democracy soon suffered from the aggressive attack of the Maoist movement of the Shining Path in the Andes, which was followed in 1982 in Lima by a Castrist movement, Tupac Amaru, which was founded by Victor Polay-Campos, son of the Aprist Victor Polay-Risco who was the grandson of the coolie, Po Leysen. The violence and the economic crisis broke the impetus which had been generated by the return of President Belaunde from which the Chinese and Tusan entrepreneurs had hoped to benefit. The arrival of the APRA in 1985 would only aggravate the situation. The urban guerrillas, led by Tupac Amaru in particular, attacked the entrepreneurs. The Tusans were plaqued by kidnapping and obliged to pay the revolutionary tax which hurt their businesses, notably in the case of the largest distributor of paper supplies in Peru, Laukong. ${ }^{53}$ All the related commercial activities, Chinese as well as Tusan, slowed down and the Chinese quarter was deserted because of the terrorist attacks. However, during these years the Chinese migratory current into Peru resumed and the new migrants discovered Lima la horrible. ${ }^{54}$

The individual enthusiasm born after the years of restriction on the neoliberal policies of the second Belaunde government was not sympathetic to the preservation of the old values. The situation within the Tusan Club also was

52 The father of Victor Polay Risco, Po Leysen arrived in Peru in 1864 and was sent to work in a sugar factory in Paramonga to the north of Lima. This is the greatest sugar cane producing region and also one with the highest concentration of coolies and Chinese workers. It is also in this region (Trujillo) that APRA was born and where the most numerous revolts of agricultural workers took place. V. Polay-Risco, agitator and militant, was one of the founders of APRA. His son, Victor Polay-Campos, founded in 1982 the movement of the Tupac Amaru guerrillas.

53 Jorge Lau Kong, owner of this enterprise, was congressman and minister in 1993.

${ }^{54}$ Title of a novel written in 1960 by Sebastian Salazar Bondy. 
far from settled. In an open letter to the community, Raul Chang, who succeeded his father as head of the Oriental, proposed in an address to the Tusans, who were also the parents of pupils of the school Juan XXIII, to join him in forming the CCPCh or the Peruvian-Chinese Cultural Center. According to the statute, "Peruvians of Chinese ascendance will be members, and also foreigners of Chinese origin, without discrimination concerning social, economic, political or religious status" (Oriental, 1981, $\mathrm{n}^{\circ} 586$ ). The definition of Tusans had become increasingly broad in meaning, as more and more Chinese entered Peru with the opening of China. The Peruvian-Chinese Cultural Center was inaugurated officially on 30 August 1981, but the hopes of this group of Tusan parents, shared later by some of the new migrants, were much too ambitious, given the situation of crisis which was soon to strike Peru. With a view to building a recreation center for themselves and their children, following the example of other communities in Peru such as the Italians and the French, and the Tusans of Guayaquil, they bought a piece of land 16 kilometers north of Lima. But during the following years they were obliged to give up their project in the face of the economic crisis and hyperinflation while above all having to cope with the presence of small groups of the Shining Path in the neighboring commune. Together with the secondary school, John XXIII, their piece of land was divided in two; the part belonging to them was called Villa Tusan while the part managed by the Franciscans was called Villa Asis. It would be nearly 20 years later and after much effort was made before the Villa Tusan finally materialized, much to the gratification of its founders. Villa Tusan, with its chapel, offered the community a place of retreat.

\section{New Flux of Immigrants}

Just as it is impossible to give the exact number of Chinese living in Peru and those who can be considered (or who consider themselves) Tusans, it is also impossible to know the exact number of Chinese immigrants entering Peru between 1980 and 2008 .

The 1981 census recorded 1,714 Chinese residents in Peru compared to 19,915 in 1940 . The figures obtained from the DIGEMIN ${ }^{55}$ for the period 1994 - first semester of 2004 show that there were 3,216 entries into Peru and 2,398 departures, i.e. a migratory surplus of 818 persons. However, also from the same DIGEMIN figures, we know that there were apparently 18,604

55 Direcion General de Migraciones y Naturalización (General Direction of Migration and Naturalization). 
Chinese who were naturalized between 1990 and 2003. The migratory surplus is underestimated because of the many cases of illegal entry. As for the cases of naturalization, they do not correspond to any real figures as they do not include the cases where Peruvian nationality was offered for sale during the Fujimori presidency in $1994 .^{56}$ The last bulletin of the DIGEMIN of 2008 indicates that between 2001 and 2007 there was a migratory surplus of 3,780 people of Chinese nationality, 2,702 of whom for the one year of $2006 .{ }^{57}$ These official figures purposely do not take into account the large numbers of illegal immigrants even when they are detained by the police.

If the official figures relating to the Overseas Chinese in Peru are lower than the actual numbers, those produced in Asian countries are, it seems, exaggerated and untrustworthy. According to the Overseas Chinese Economy Yearbook of Taipei, there were in Peru, in 1987, 39,000 people in the category of Overseas Chinese (the criteria for which are unspecified) and 500,000 people in 1991 (Poston 1994: 637). Some other sources go as high as 800,000. One wonders how many generations are counted, and what degrees of mixed blood entered into these calculations? In reality it is already difficult to know the number of people composing the primary circle of the community and that of the second-generation Tusans. It is even more difficult to do the same with the third category which includes the half-bloods.

In 1980, when a number of Cantonese entered Peru (many staying illegally once their temporary visas expired) to join their families, networks of clandestine entries were also formed within the DIGEMIN, designed to help all those who did not have visas to enter the country. These networks, as mentioned previously, became even more powerful during the ten years of the Fujimori regime. Several people from the Chinese and Tusan community were held for questioning as was the Tusan minister Victor Joy Way. Other Chinese entered Peru as managers or workers in the steel industrial complex that the Shougang-Hierro-Peru company had bought back from Peru in 1992 under

\footnotetext{
${ }^{56}$ From 1990 and the coming to power of A. Fujimori, Peru's relations with Asia changed. Japan came prudently closer to Peru, Taiwan wanted to profit from Peru's opening to Asia, and APEC looked to investing in Peru. The British companies sought to place their funds in Peru before the retrocession of Hong Kong to the People's Republic. The Taiwanese-Hong Kong mafias wanted to profit from a new law — in force from March to June 1994 — offering Peruvian nationality on a deposit of $\$ 20,000$ from Chinese entrepreneurs wishing to settle in Peru. A bogus company, Blooming Strong Development, was then set up, to run a new enterprise dealing in Asiatic immigration. The Senate which denounced the "sale of Peruvian passports" and the resulting scandal put an end to this attempt by the Mafia to organize under cover of legality an illegal immigration scheme serving as Chinese money laundering (Demelas and Lausent-Herrera 1995: 23).
}

${ }^{57}$ http:www.digemin.gob.pe/estadisticas.asp 
the privatization scheme. These workers were not Cantonese and did not integrate. As for the Cantonese who continued to arrive, the fate awaiting them was not what they had expected. They were sometimes exploited, particularly if they worked in the restaurants and family factories, before being able to establish themselves. Generally, the enthusiasm of the Peruvians for Chinese food was in their favor. Once their debt was paid (for airplane ticket, fees for administrative procedures, false residence papers, etc.), they contributed to the setting up of Chinese restaurants in all quarters of Lima. Their relocation to the provinces (far from the Chinese quarter and the inhabitants of Lima who were accustomed to the sight of numerous Chinese) only took place after 1992 with the pacification of the country. It should not be forgotten that they had arrived in Peru while the country was going through its worst social and economic crisis. For many this came as a shock because on top of the poverty and hyperinflation, they had to deal with violence and the danger of terrorist attacks. But neither the moribund economy nor the state of insecurity in the country slowed down the flow of the new migrants into the country.

Where Cantonese immigration is concerned, there are many cases that are worth mentioning. Many of the migrant women (nearly 40 percent of the total) came from rural families or outlying suburbs with a number of children. According to them, their families in China wanted them to leave so that they would not be a burden at home. ${ }^{58}$ The work they found in Peru was usually linked to the Chinese restaurant business or the Chinese food industry and later to sales, after they had acquired a little Spanish. The men too took up mostly restaurant work and received low wages. When they succeeded in freeing themselves, they opened small shops linked to the import of products which were often of low quality except for those destined for the restaurants. Those who had the support of the family, emotional or otherwise, or who found in the huiguans of their home counties the necessary help to develop other activities, managed to integrate into the community where, thanks to their knowledge of Chinese and their "legitimacy," they tended to take up responsible positions in the traditional associations and adjust quickly in the community. When they became richer, they went into business; some became owners of furniture or Chinese foods factories or proprietors of hotels or casinos.

But within a relatively short time, the migration flow which was limited to 15 or so counties from the province of Guangdong changed drastically into

\footnotetext{
58 On this theme, see the different testimonies gathered from the Chinese women in LausentHerrera (2007). Even when earning a factory worker's salary which they sent back to their parents, these young women were considered a hindrance to the enrichment of the family or the education of a son.
} 
human trafficking on a large scale because of the involvement of the mafia. From then on Peru became a place of transit for those coming from Guangdong and Fujian whose ultimate destination was the United States or Canada.

\section{Proud to be a Tusan: Celebrations and a Providential Leader}

After nearly breaking apart because of the consequences of their disengagement from China and the political conflict which weakened the country during the preceding two decades, the Tusans of Peru found a renewed dynamism which until then had been employed in maintaining their identity almost exclusively by holding onto their attachment to the Catholic Church. The year 1999 was significant in this context. A national program was launched to organize public discussions and publish works concerning the national and non-national minorities which make up the cultural diversity of the Peruvian nation. Two important symposiums were organized by the Fondo Editorial del Congreso del Perú, one relating to the 100th anniversary (1899-1999) of the arrival of the Japanese in Peru, and the other concerning the 150-year history of the Chinese presence in Peru (1849-1999). The second event was dreaded by the discrete Beneficencia China which feared that too much attention would be paid to the period of Chinese coolies - a subject of study for most of the researchers - and that the occasion would lead to the emergence of a new class of Tusans led above all by a leader such as they had never encountered.

Everything began in 1942 when Erasmo Wong, a Chinese who had arrived in the 1930s and opened his bodega (grocery store) in the upper middle class quarter of San Isidro. The location of the store, the quality of his products, the warm welcome he gave the clients and the on-going modernization of his sales techniques enabled his business not only to survive but grow spectacularly. Together with his children, ${ }^{59}$ all university-educated in different fields, Wong expanded his business. Before long, the Wong supermarkets were set up everywhere in Lima and the provinces. These days, the figurehead of the Wong commercial empire ${ }^{60}$ is Erasmo Wong Lu, the son. The 8,000 employees are very well treated and celebrate May 1st every year by putting on a show for the public. But what the inhabitants of Lima appreciate the most is the national holiday parade, an immense, extremely colorful and joyful event followed by

\footnotetext{
59 Erasmo, Efrain, Eduardo, Edgardo, Eric and Edna (note the E of each given name chosen to indicate the same generation). There are other similar cases among Tusan families.

${ }^{60}$ Concerning the worth of this group, see Yamada and Chacaltana (2007: 75-83).
} 
a setting off of firecracker which the Wong enterprise organizes every year, and which even the government cannot offer to its citizens. The Peruvians have taken Wong to their heart; for them he is not only someone who has improved their daily life but who has also enhanced the well-being of Peruvians over and above their Chilean competitors. ${ }^{61} \mathrm{He}$ is actually worth 500 million dollars.

In 1999, Erasmo Wong Lu decided to take in hand the commission overseeing the celebration of the 150th anniversary of the Chinese presence in Peru. To do this, he surrounded himself with a certain number of Tusan Chinese from among the young entrepreneurs. The symposium adopted the spirit of the album published in 1924 by the Chinese community showing what the Chinese had given to the national economy, and would above all give a new place and preponderance to the Tusans, highlighting their intellectual as well as economic success. ${ }^{62}$ This celebration of the Tusans was made easier by the great visibility which they had enjoyed for ten years, as the first Fujimori government had included numerous collaborators and ministers of Asiatic origin. ${ }^{63}$

Using his economic clout and social prestige, Erasmo Wong Lu financed the repairs of the main street of the Chinese quarter, the calle Capón, which was decorated to accentuate its Chinese character. He also took advantage of his status in a number of Tusan institutions such as the CCPCh to gather around him the Tusan elite of his generation, i.e. those between 40 and 50 years old who were recognized for their success in different fields such as commerce, finance, the upper echelons of the civil service and academia. This new elite who had not yet found its place either within the Beneficencia China or in institutions that were too closely-linked to the Church (the CCPCh) or to recreation (the Tayouk Club), would surround Erasmo Wong Lu with men of excellence and function as a network of influence, the very illustration of the culture of guanxi. His association, the APCH or Asociación Peruano China, thus came to be known in all Peru as the symbol of awakening vis-à-vis the

${ }^{61}$ Since the Pacific War (1879-1883) during which Peru was occupied by Chile, there has been a strong anti-Chilean sentiment manifesting itself particularly in relation to Chilean investments in Peru especially relating to two chain stores.

${ }^{62}$ In October 1999 the historian Celia Wu-Brading, professor at Cambridge, Eugenio Chang Rodriguez, professor of literature at New York University, and José Chang, rector of the University San Martín de Porres, participated in the forum on Tusan intellectuals.

63 Between 1990 and 2000, besides having developed an "Asiatist" economic policy, taking as a model the development of the Asian tigers and taking Peru into APEC (Asia-Pacific Economic Cooperation), Fujimori surrounded himself with a number of Tusans and Nikkei. Among the Tusans: Victor Joy Way, Minister of Energy and Mines, Prime Minister, President of Congress (now in prison for serving as broker for a Chinese pharmaceutical company), J. Lau-Kong, Martha Chavez, L. Chang Ching, J. C. Lam and J. C. Chu-Rubio. 
lethargy of the old institutions, in part in answer to the ever growing presence of China in the Peruvian economy and the new immigrant entrepreneurs.

The goals of Wong's APCH are the search for identity and the attainment of economic success. In its Boletín Informativo Integración published in 2001 (8,000 copies), the reference to the Tusan identity appears explicitly as the motor of any undertaking. Four moral principles should dictate the conduct of the Peruvian Tusans: hard work, trustworthiness, honesty and respect for the elderly. However, the term Integración appears in the title of the bulletin only after the third year of its appearance. This term poses problems. Why would the descendants of the Chinese Peruvians, known throughout Peru as the Tusans and particularly well integrated, their visibility growing ever since the era of the Fujimori government and the success of the Wongs, need to reconstruct an identity around the theme of integration? One wonders if the desired integration is one which would position them for globalization, making them the necessary intermediaries between China and Peru? Even if this interpretation is correct, it is ultimately the Tusans' need for recognition in Peruvian society which predominates. It appears therefore that integration, as conceived by the APCH, should break down the sense of isolation felt by certain Chinese descendants who are prisoners of their milieu, and who should now prepare themselves for the globalization in which China is an important player.

For Julio Chang Sanchez, director of the APEC (Asia Pacific Economic Cooperation) at the Foreign Trade Ministry, "the role of the Tusans is to assemble the efforts and promote foreign trade and investments... Become the motor and the spearhead of trade between Peru and China, and fortify relations with Asia" (Integración, APCH, n 37, 2007). He adds, "[W]e should make known the existence in Peru of a large Chinese community which would surprise and interest more than one [...], and would allow us and our associations to establish new personal and economic links." According to the APCH, "the community's support of the work carried out by the government in the framework of the presidency of the APEC 2008 is fundamental and permits us to form relations with other communities on the other side of the Pacific" (Oriental, 2007, n 923 , p. 23).

In this spirit, the APCH organized in 2005 and 2007 meetings of the Tusans, "Los Herederos del Dragón" (Heirs of the Dragon) in collaboration with the prestigious ESAN, the Business School. These meetings, plus their work on the theme of relations with China, also allowed the Tusans who had succeeded in business or in the administration to transmit their experience to members of the younger generation, and, when the latter prove their worth, ${ }^{64}$

${ }^{64}$ Another institution, the CAPECHI (Association of the Peruvian-Chinese Chamber of 
to support them. The young Tusans (from 20 to 40 years old) who had joined the association APCHyouth could, on production of a letter of motivation, benefit from study groups conducted by people well-known in the business world. The aim was to make this generation of Tusans become leaders in the world of finance and business, "who would have positions of influence, [and] who would direct and have great ambition" (Integración, APCH, n 33, 2006). On their part, the young Tusans were aware that in entering into this privileged circle they would be part of a network of social contacts, or guanxi.

\section{Tusans versus New Immigrants}

New Chinese migrants may be divided into four categories. The first consists of mainly Cantonese who began to arrive in the early 1980s, following in the footsteps of the traditional Chinese immigrants. As has been mentioned, the conditions under which they arrived were not always easy; they had to endure the abuse of foster families, pay off debts and live through the Peruvian economic and political crises. The first arrivals came via the traditional networks, more or less legally assisted by the huiguans, and the more recent arrivals are smuggled in by "snakeheads." ${ }^{65}$ For at least 20 years in Peru, if they did not spend time in other countries during that period, these migrants would have by now, in varying degrees of success, their own businesses, mostly in restaurants and small industries located in the suburbs of Lima. Some of the more successful have become presidents of huiguans, replacing the older generation which favored Taiwan, or members of the directorship of the Beneficencia China which obliges them to show allegiance with the Embassy. One of the examples of this success is Alan Chang, owner of the Wa Lok restaurants (Yamada and Chacaltana 2007: 63-73). After this group of successful men comes the next legitimate generation of Tusans consisting mainly of those born of Chinese fathers and mothers.

The second category is made up of immigrants from Fujian. There were immigrants from Fujian in the past as shown by the abandoned premises of their huiguans (Lausent-Herrera 2000: 54). ${ }^{66}$ Their association, Hokkien

Commerce) has the same aim but its members are above all Peruvians and the few Tusans and Chinese who participate in it are directly linked to the Chinese Embassy in Peru.

${ }^{65}$ Between December 2006 and February 2007, two boats with 100 Chinese each were captured by the coast guards, one to the north of Peru and the other adrift along Costa Rica. The snakehead of the Dragón Rojo stationed in Lima, who was responsible for this failure, was immediately executed.

${ }^{66}$ Lausent-Herera (2000: 54). The premises were bought in 1879 but abandoned for several years. 
Gongsi, indicates that they originated in the south of Fujian Province. The present migrants are not related to the former migrants; they came from eastern Fujian and their Fuzhou and Fuqing dialects are incomprehensible to the local Cantonese and Hakkas. They arrived in Peru at the end of the 1980s via an illegal immigration network which could take the migrants first to Peru and then north to the United States, following the same route as the Latin American migrants but with leaders from the network, or to settle in Lima. The first Fujian migrants were all men but very soon the women arrived, almost as many as the men, followed by the couples' parents, to take care of the children. These days we see the entry of single women. The Fujian migrants who occupy numerous premises in the Chinese quarter are not well accepted by the Cantonese. Mafia-like activities often related to Chinese restaurants are linked to their presence injecting fear in the community and Beneficencia China which lodged a complaint with the Embassy. As the town center and the middle class neighborhoods became saturated, they opened numerous Chinese restaurants of all categories in the Lima suburbs. They are also present in the district of San Borja where the wealthy Tusan middle class resides. They operate internet parlors, hairdressing salons and spas. Hotels are also their domain and are associated with the increase in prostitution. Four years ago they set up an association, outside the movement of the Beneficencia China which did not want to include them. But as it was implicated in the activities of an illegal immigration network, the association ceased to exist in 2007. Although the successes of the new migrants are now apparent, their failure to integrate has excluded them from the life of the Tusans. If their children do not have access to an education comparable to that of the Cantonese children, it is difficult to see how the children of these migrants will be well-integrated in the years to come.

A third group, very small compared to the migrants from Fujian, comes from the central regions comprising Hubei, Anhui and even Sichuan. They have come to Peru generally as employees of Chinese enterprises. One can group them with the immigrants, not yet numerous, from Dongbei, i.e. the three Northeastern Provinces in particular Liaoning, but also from Beijing. As in other places outside China, these are Chinese migrants with a higher level of education arriving with a small capital and looking to invest in industry and the import of Chinese computer equipment and spare parts. They tend to be drawn, as were the Taiwanese, to the free exchange zones opened in Peru about ten years ago. They are beginning to invest in the interior provinces in projects relating to the building of factories.

The fourth group is distinguished neither by its geographical origin nor its dialect insofar as it puts together the Cantonese and the migrants from Fujian. 
What unite them are the very hard conditions in which they work as cooks or employees in Lima. They are isolated and unable to leave Peru for the United States or Canada, for they do not earn enough money to pay the smugglers and have no choice but to live with false identities or outdated passports. The recent evangelical church, Alianza Cristiana Misionera (led by Pastor Michael Chang), which is affiliated to the CCCOWE (The Chinese Coordination Centre for World Evangelization), looks for its new converts in this group. In 2006 it organized the "Global Chifa Mission Conference" in Lima and succeeded in establishing itself with the new migrants, those who have no huiguans to go to and who do not expect to get help from the Beneficencia China.

The last fact is significant because, as has been seen, the cohesion of the Chinese community owes a great deal to its connection to the Catholic Church which, thanks to its associations and to its teachings, has allowed the Tusans to preserve their identity. Never before had the Catholic Church been in competition with another church or religion. ${ }^{67}$ One should note that in view of the size of the new immigrants which no one can quantify, the clergy in charge of the Chinese community has not been equal to the task. The Church offers the new arrivals a paid education but few places and few scholarships. Moreover, in order to be well informed of the aid offered by the clergy one must be wellintegrated into the Cantonese milieu which excludes the young from Fujian. In being so out of touch with the situation of the rejected members of the new immigration, the Church has interrupted a process that it has spent more than 100 years to put in place. As such, the Church is helping to put up a barrier between the Cantonese and the other groups of migrants who do not have the financial means to give their children born in Peru a good education. The following comment made by the President of Beneficencia China, Jau Kinsiu, when he was invited to celebrate the 25th anniversary of the foundation of $\mathrm{CCPCH}$, is very revealing:

I consider that as a social institution, the CCPH should try to develop the friendship and integrate the new Chinese immigrant as much as the Tusans. The new immigrant today differs in his way of thinking, of dressing, in his customs and his beliefs. Moreover, I think that it would be important to have sporting events with the new immigrants so as to recreate the unity of the Chinese community of Peru (Boletin Informativo CCPCH, $\mathrm{n}^{\circ}$ 9, 2006: 12).

${ }^{67}$ In reality there exists since 1979 within the Evangelical church of the China Alianza Cristiana a Chinese church. But this church has no Chinese-speaking pastor and also accepts Peruvians. Recently the Iglesia China of the Alliance has turned to the new migrants with success, with the help of translators from the new immigrants. Alerted to the importance of this new migratory current, the Alianza Cristiana has sent a new Chinese American pastor to intensify its mission of evangelization. Mr. Chang has allied himself with the CCCOWE and formed his own church. 
Jau Kinsiu has made a valid point. But what is surprising is that he thinks it is for the CCPCH, therefore the clergy, to solve the problem of the new migrants which was traditionally the work of the huiguans. Is Jau implying that the huiguans are no longer capable of playing their role, or does he think they have simply walked away from a traditional commitment? Are the new immigrants seen as potential competitors? There are no easy answers to these questions. The Chinese and the Tusans who claim a special identity have won recognition of their social and economic position in Peruvian society which has taken them more than one generation, with the exception of the Wongs. But just like the American dream, there is also a Chinese dream, waiting to come true.

\section{Conclusion}

Thanks to the publication, Oriental, the injerto or Chinese-Peruvian halfblood won dignity, recognition and visibility in the 1930 s by becoming simply a Tusan, that is, almost the equal to the child born in Peru of a Chinese mother and father. He learned to count very little on the paternal institution and preferred to form his own institutions to keep his Chinese identity while becoming an example of integration.

The Church understood that it was in the child's interest to maintain his/her identity and took the place of the traditional huiguans; the clergy can thus be looked upon equally as the founder of the great Tusan family. One may criticize the Church for keeping the Tusans from losing their identity the better to prevent them from leaving it, but it should be recognized that in so doing, the Church has actually brought about the emergence of a well-integrated elite in Peruvian society.

The majority of former huiguans have had difficulty in maintaining their traditional form, some of them even selling their premises or renting out a part to operators of slot machines in order to increase their income. Their directors are aging and slowly being replaced by the immigrants arriving in the 1980s. These late comers, although already accustomed to Peru, do not have the same romantic, cultural references and are guided by pragmatism. Soon to become the majority, they will doubtless not be concerned with conserving the long heritage of 160 years of Chinese presence in Peru. As they have said themselves, they do not feel they are the guardians of the patrimony they have received. For the first time in decades, a new huiguan was recently inaugurated, assembling those coming from Dongguan. It is the only huiguan where an understanding exists between the former migrants (previously attached to the Panyu huiguan) and the new arrivals, mostly small investors, and which 
approximates a traditional form of association, while the present tendency is for huiguans to disappear or be reconstructed.

On the other hand, the Tusans of today, coming from the Sino-Peruvian community, are very concerned about the preservation of the institutions; they are fighting to preserve this heritage which is testimony to their legitimacy as Tusans. But here again changes are foreseeable. Contrary to the thinking of Erasmo Wong $\mathrm{Lu}$ and his declaration made at the time of the creation of his APCH-youth, the Tusan tradition will not pass forever from generation to generation even if the practice of intermarriage has allowed certain families to claim to be Tusans for two or three generations. Within APCH-youth, dissensions have appeared: the young arriving from China with their parents in the 1980s or those born in Peru to new immigrant families have begun to contest the legitimacy of the term Tusans for those born in Peru of mixed parents, for those in the second and third generations, or again for those who do not have a Chinese family name, a fact that actually means nothing in Peru since a great number of Chinese have Spanish names. This debate is quite revealing of the state of mind of certain young people who, influenced by a strong nationalist Chinese sentiment, attribute to themselves qualities superior to those of the Peruvians. In other words, they are saying that not just anyone - among the half-bloods - can claim to be Tusans. This new situation is totally opposite to the one in 1931 which led the descendants of the Chinese of Peru to group together. But perhaps one can say that these young Chinese-Tusans who would like to profit from the APCH have at least in common with its founders a great admiration for the economic success of China. ${ }^{68}$

Another sign of change has become noticeable in recent years. Certain Tusans are beginning to be referred to and to refer to themselves as Wah Joy or Huayi. Little by little the term Huayi is gaining ground particularly in the journal Oriental where it is used more and more often. Should one see in this the increasing influence of mainland Chinese culture? Has the term become a form of identification? If the Tusans allow themselves to be supplanted by the Huayi, this would be extremely significant. This is not impossible as China has great draw and the sense of identity for the Tusans is diminishing in the process of globalization in which the individual becomes a part of the encompassing whole. The Chinese Embassy in Peru which in the past had been little inclined to support cultural activities, is now encouraging them notably in the establishment of the Confucius Institutes which control the teaching of

\footnotetext{
${ }^{68}$ Another interesting aspect of these young people is their negative response when asked if they will marry Peruvians, an attitude stemming no doubt from that of the parents who do not want mixed marriages for their children.
} 
Chinese and cultivate the young from the new generation of Tusans. Erasmo Wong Lu may have faith in the future of the Tusans, he will nevertheless have to accept the possibility that in a few years from now the new Chinese community will no longer share the same past as the present generation and that it will undoubtedly have a different dream of its future.

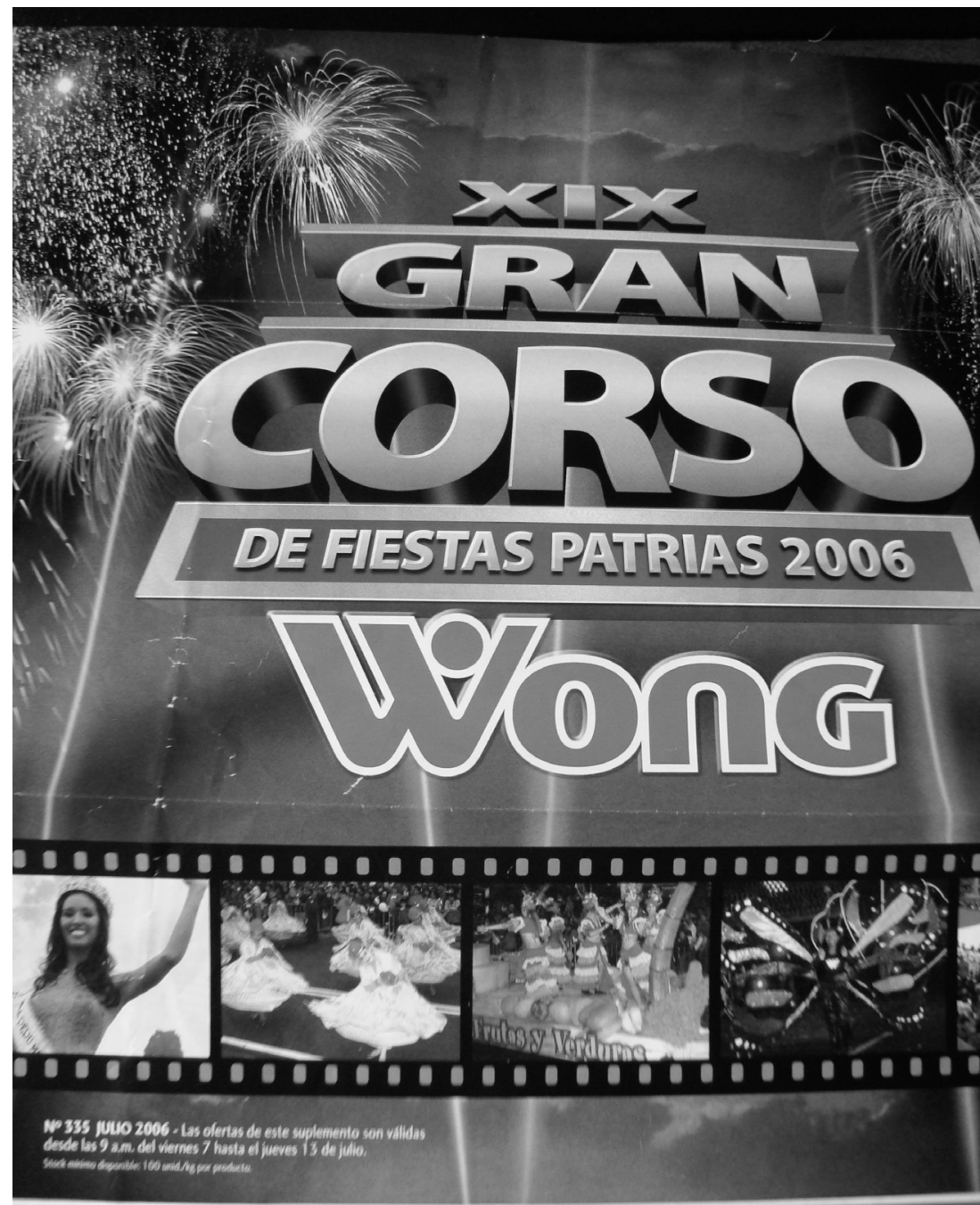

\section{Domingo 23 de jullo - 3 p.m. - Mira}

Since 1987, the E. Wong Tusan's commercial empire has organized a huge parade every year on national day. 


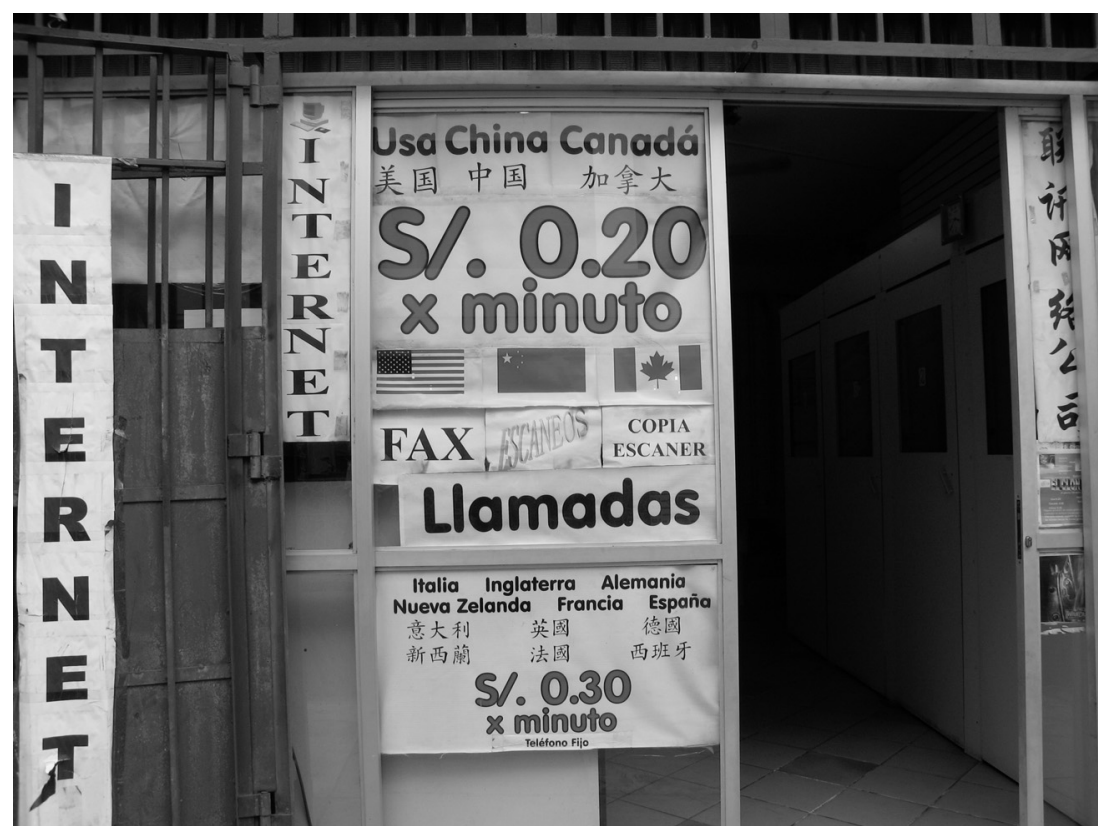

Pluto Street in Lima's Chinatown. Since 2000 there has been a significant increase in the number of internet parlors that allow new migrants to keep in touch with their relatives in China and the Chinese diaspora elsewhere.

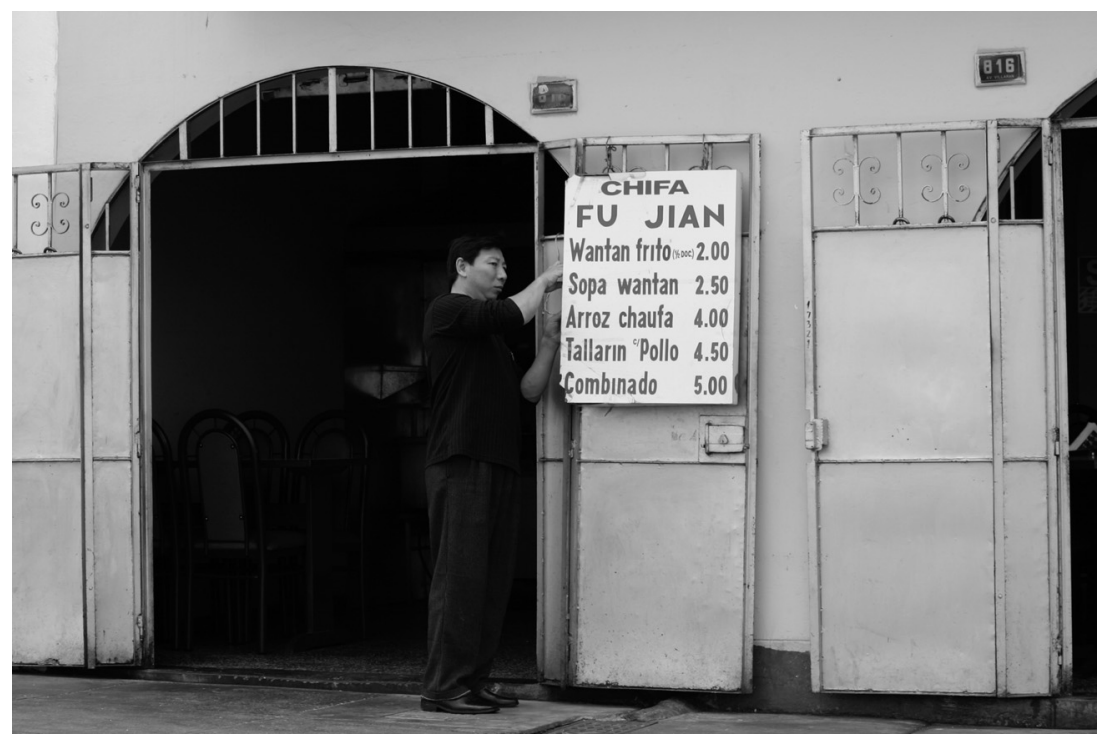

Fujian immigrant who has taken over a small chifa (Chinese restaurant) in a popular neighborhood in Lima. 


\section{References}

Archivo General de la Nación (AGN) Protocolos Notariales Terán Tomo 647, 1891, Tomo 906, 1888.

Archives of the Ministry of Foreign Relations, 8.23A: Peruvian Consulate in Hong Kong, May 22, 1909.

Biblioteca Nacional del Perú (BNP). Miscelánea Zegarra.XZ.V.58: 37.

Anon. 1924. La Colonia China en el Perú. Instituciones y hombres representativos. Sociedad Editorial Panamericana. Lima.

Alvarez Vita, Juan. 1990. Diccionario de peruanismos. Editora Studium. Lima.

Bilu Zhonghua Tonghui Zongju, ed. 1986. Bilu zhonghua tonghui zongju yu Bilu huaren. Lima.

Cook, David Noble. 1985. Numeración general de todas las personas de ambos sexos, edades y calidades que se ha hecho en la ciudad de Lima, año de 1700. COFIDE, Oficina de Asuntos Culturales 1985. Lima.

Cotteau, Edmond. 1886. Promenades Dans les deux Amériques 1876-1877. Charpentier. Paris.

Cuche, Denys. 1976. "Système de plantation et relations interethniques." Pluriel nº 6, pp. 13-26.

Demelas, Marie Danielle; Lausent-Herrera, Isabelle. 1995. "Pérou : le Pouvoir selon Fujimori." Problèmes d'Amérique Latine $\mathrm{n}^{\circ} 19$, pp. 1-25. Paris.

Estenssoro Fuchs, Juan Carlos. 2000. "Los colores de la plebe: razón y mestizaje en el Perú colonial." In Los cuadros del mestizaje del virrey Amatl La representación etnográfica en el Perú colonial. Natalia Majluf, ed. Museo de Arte, pp. 67-107. Lima.

Ho, Mingshu. 1967. Manual de la Colonia China en el Perú. Lima.

Lausent, Isabelle. 1983. Pequeña propiedad, poder y economía de mercado: Acos, IEP-IFEA. Lima.

Lausent-Herrera, Isabelle. 1991. Pasado y Presente de la Comunidad japonesa en el Perú, Lima col. Mínima. IEP-IFEA. Lima.

— - 1992. "La cristianización de los chinos en el Perú: integración, sumisión y resistencia." Bulletinde l'Institut Français d'Etudes Andines n 21(3), pp. 997-1007. Lima.

—. 1996. "Los caucheros y comerciantes chinos en Iquitos a fines del siglo XIX (1890-1900)."

In Las raíces de la memoria. América latina. Pilar Garcia Jordan et al., eds. Universitat de Barcelona.

—. 1997. "L'émergence d'une élite d'origine asiatique au Pérou." Caravelle $\mathrm{n}^{\circ}$ 67, pp. 127-53.

1998 "Frentes pioneros chinos y desarrollo regional en la selva central del Perú." In $L a$ nacionalización de la Amazonia. Pilar Garcia Jordan y Nuria Sala y Vila, eds. Universitat de Barcelona.

— 2006 "Mujeres olvidadas: esposas, concubinas e hijas de los inmigrantes chinos en el Perú republicano." In Mujeres, Familia y Sociedad en la Historia de América Latina. Siglo XVIII-XXI. Scarlett O'Phelan Godoy y Margarita Zegarra Flores, eds. IFEA, PUCP, CENDOC, IRA. Lima. — 2007. "Paroles de femmes dans l'immigration chinoise au Pérou." Diasporas, n ${ }^{\circ} 11$, pp. 37-56. Toulouse.

- 2008. "La Captación de la Fe de los Nuevos Inmigrantes Chinos y de sus Hijos por las Iglesias Católicas y Evangelistas." In República Creyente. Religión, diversidad y política en el Perú contemporáneo Fernando Armas Asín et al. Editores, Instituto Riva Agüero (in print). Lima.

Leibner, Gerardo. 1997. "Pensamiento radical peruano: Gonzales Prada, Zulen, Mariategui." Cuadernos Americanos, N 66, pp. 47-66. México.

McKeown, Adam. 1996. "La inmigración China al Perú, 1904-1937; Exclusión y negociación" Histórica Vol.XX n ${ }^{\circ} 1$ july, pp.59-91. Lima.

- 2001. Chinese Migrant Networks and Cultural Change. University of Chicago Press.

Middendorf, Ernest. 1973. Perú. Observaciones y estudios del pais y sus habitantes durante una permanencia de 25 años. TI, UNMSM (1ère éd.1894). Lima. 
Ministerio de Gobierno Policía y Obras Públicas. 1878. Censo General de la República del Perú formado en 1,876, 7 tomos. Imp. del Estado. Lima.

Ministerio de Hacienda y Comercio, Dirección Nacional de Estadística. 1940. Censo Nacional de Población y Ocupación de 1940. 2 Volúmes. Lima.

Monnier, Marcel. 1890. Des Andes au Para. Paris.

Palma, Clemente. 1897. El porvenir de las razas en el Perú. Tesis de Doctorado en letras, UNMSM. Lima.

Poston, Dudley-Mao; Michael Xinxiang-Yu; Mey-yu. 1994. "The global distribution of the Overseas Chinese around 1990." Population and Development Review 20, n 3, pp. 631-45.

Roca, Luis. 1985. La otra historia. Instituto de Apoyo Agrario, Lima.

Rodríguez Pastor, Humberto. 1979. La rebelión de los rostros pintados. Pativilca, 1870. Instituto de Estudios Andinos. Lima.

—. 1991. "Negros y Chinos en la Historia Peruana Contemporánea." Socialismo y Participación $\mathrm{N}^{\circ}$ 55, septiembre de 1991, pp. 69-74. Lima.

Santisteban, Sixto. 1905. ¡Peru Adelante! Callao.

Sociedad Editorial Panamericana. 1924. La Colonia china en el Perú, Instituciones y Hombres representativos: su actuación benéfica en la vida nacional. Lima.

Siu, Kamwen. 1985. El tramo final, Lluvia editoriales. Lima.

Universidad Nacional Mayor de San Marcos (UNMSM), 1968. Padrón de los Indios de la Provincia de Lima en 1613. Lima.

Yamada, Gustavo; Juan Chacaltana. 2007. La generación de empleo en el Perú: seis casos recientes de éxito. Universidad del Pacífico. Lima. 